\title{
HOSPITALITAS DALAM HUBUNGAN SUAMI ISTRI YANG BERBEDA AGAMA DI LEMBANG PA'TENGKO
}

\author{
Alfri Tandi \\ Mahasiswa Institut Agama Kristen Negeri Toraja \\ alfritandi17@gmail.com
}

\begin{abstract}
In Toraja there are many family members of different religions, even under one roof of the house there are family members of different religions. In general, Islam and Christianity. There are even married couples who have different beliefs or religions. This was especially the case in lembang Pa'tengko where there were families between husbands and wives adhering to different religions and living in one and having descent. This study uses a qualitative approach, which examines empirical truth in one family in Lembang Pa'tengko. The purpose of the study was to find the factors they apply to their families so that their families remain harmonious despite religious differences. In essence, religion has an important role in creating peace. Between husband and wife can not be separated from the relationship and work together every day. But sometimes they also get teachings from their respective religious doctrines, but this is responded to with a healthy and wise ratio. None of them is selfish and accentuates an attitude of wanting to dominate because they build relationships of mutual respect or hospitality for the sake of creating harmony in their family.
\end{abstract}

\section{Key Words: Hospitality, religion, tolerance, peace / harmony}

\begin{abstract}
Abstrak: Di Toraja terdapat banyak anggota keluarga yang berbeda agama, bahkan di dalam satu atap rumah terdapat anggota keluarga yang berbeda agama. Pada umumnya agama Islam dan Kristen. Bahkan ada pasangan suami istri yang memiliki keyakinan atau agama yang berbeda. Khususnya yang terjadi di lembang Pa'tengko di mana terdapat keluarga antara suami dan istri menganut agama yang berbeda dan tinggal dalam satu serta mempunyai keturuan. Penelitian ini menggunakan pendekatan kualitatif, dimana meneliti kebenaran yang empiris dalam sala satu keluarga di Lembang Pa'tengko. Tujuan dari penelitian untuk menemukan faktor-faktor yang mereka terapkan dalam keluarga sehingga keluarga mereka tetap rukun meski dalam perbedaan agama. Pada hakikatnya agama mempunyai peran penting dalam menciptakan kedamaian. Antara suami dan istri tidak terlepas dari relasi dan saling bekerja sama setiap hari. Namun terkadang juga mereka mendapat ajaran dari doktrin agama masing-masing, namun itu ditanggapi dengan rasio yang sehat dan bijak. Diantara mereka tidak ada yang egois dan menonjolkan sikap yang ingin menguasai karena mereka membangun hubungan yang saling menghargai atau hospitalitas demi terciptanya kerukunan dalam keluarga mereka.
\end{abstract}

Kata-Kata Kunci: Hospitalitas, agama, toleransi, damai/rukun

\section{Pendahuluan}

Keluarga tergololong ke dalam hal yang sekunder dalam kehidupan ini. Perbedaan dalam keluarga khususnya perbedaan agama itu sudah hal yang biasa dalam masyarakat Toraja khususnya di Lembang Pa'tengko. Namun anggota keluarga memperlihatkan sikpa yang hospitalitas sehingga tidak terjadi kekacauan. Hopitalitas merupakan suatu bentuk keramatamahan yang diberikan oleh satu individu ke individu lainnya. ${ }^{1}$

Persoalan atau masalah tidak terlepas dalam suatu rumah tangga. Dalam setiap rumah tangga tentunya ada perselisihan yang disebabkan karena adanya kesalapahaman antara suami dan istri dan orang tua dengan anak. Banyak metode yang digunakan untuk mencega perselisihan yang terjadi ini, demi terciptanya keluarga yang harmonis meski dalam perbedaan. Karena kondisi yang

\footnotetext{
${ }^{1}$ Daniel Fajar Panuntun, “Nilai Hospitalitas Dalam Budaya Longko' Torayan,” in Teologi Kontekstual Dan Kearifan Lokal Toraja, 2020, 20
} 
damai dan stabil merupakan syarat mutlak bagi kemajuan pembangunan dan kesejahteraan masyarakat baik fisik, maupun rohani. Sebagai bangsa yang menjunjung ketuhanan, maka secara religius masyarakat indonesia masing-masing bebas memuluk agama dan kepercayaan yang beragam.

Senada dengan itu, karena dengan terciptanya suasana yang rukun dalam sebuah kelauarga maka akan terjadi kedamain dan ketentraman dalam keluarga, dan dengan demikian akan mendorong semangat dalam menjalani kehidupan dalam bekerja, karena adanya harapan dan tujuan untuk keluarga kecil. Hal ini akan menciptakan kesejahteraan baik jasmani maupun rohani dalam sebuah kelaurga. Di indonesia terdapat tujuh agama yang dilegalkan oleh negara, itu berarti bahwa masyarakat Indonesia berhak memeluk salah satu dari agama tersebut sesuai dengan kenyamanan diri seutuhnya dengan catatan tidak membuat keributan atau kriminal. Dan bahwa masing-masing agama harus saling menghargai (tidak menista agama/kepercayaan lain).

Akan tetapi dengan tidak menyatuhnya kepercayaan dalam sebuah keluarga berdampak pada anak yang bingung harus mengikut siapa bahkan terjadi perpecahan karena adanya paham-paham yang berbeda dalam sebuah agama dan doktrin yang disampaikan dan didengar oleh mereka berbeda pula. Karena pada hakikatnya agama mempunyai benih radikalisme. Yang dimaksudkan di sinih bahwa setiap agama mempunyai kzeyakinan yang kokoh pada ajaran agama yang dianut hingga ke yang paling substansial. Sesuai dengan hak di Indonesia masyarakat bebas memeluk agama akan tetapi masalah akan terjadi ketika adanya radikalisme dan juga sifat yang fundamentalisme. Dengan adanya sikap seperti ini maka tentunya akan terjadi pertikaian bahkan berujung perpecahan. Deklarasi HAM Universal 1948, Perjanjian International Mengenai Hak-Hak Sipil Dan Politik (ICCPR) Pasal 19 (2) hak atas kebebasan ekspresi dalam beragama. Misalnya konvensi Eropa pasal 10 (1), Konvensi Amerika, pasal 13 (1), 1981 Africhan Cahrter pasal 9, serta perjanjian Internasional Hak-hak Ekonomi Sosial dan Budaya.

Melihat hal ini sebenarnya pemerintah bahkan dunia sejak dahulu sudah memberi perhatian dan menjamin kebebasan dalam menjalani kehidupan khususnya hak untuk memeluk agama. Jadi dengan demikian masyarakat tidak takut atau kwatir lagi untuk memeluk agama yang menurutnya baik dan ia dapat menerima dengan seutuhnya. Dengan demikian masyarakat akan hidup damai dengan dirinya secara spiritual dan bahkan fisik. Hal ini diberi perhatian yang cukup oleh pemerintah Indonesia. Karena Indonesia adalah negara hukum, maka bentuk perhatiannya, mereka menuangkan peraturan dalam undang-undang yang menjamin hak dan kebebasan penduduknya. "Hak untuk hidup, hak untuk tidak disiksa, hak kemerdekaan dan pikiran dan hati nurani, hak beragama, hak untuk tidak diperbudak, hak untuk diakui sebagai pribadi di hadapan hukum, dan hak untuk tidak dituntut atas dasar hukum yang berlaku surut adalah hak asasi manusia yang tidak dapat dikurangi dalam keadaan apapun". ${ }^{2}$ Hubungan antar agama akan baik ketika penganutnya saling menghargai, saling menghormati, menghargai kesetaraan dalam pengajaran agamanya dan saling bekerja sama dalam rumah tangga mereka serta meningkatkan sikap yang toleransi antara mereka.

\footnotetext{
${ }^{2}$ Naomi Sampe, “Menangkal Radikalisme Agama Melalui Akulturasi Agama Dan Budaya Toraja,”in Teologi Kontekstual Dan Kearifan Lokal Toraja,2020, 102-122.
} 
Setiap agama memiliki dogma yang mengajarkan kebaikan dan bukan kejahatan. Sikap terhadap dogma inilah yang harus dikembangkan dalam menjalani kehidupan yang hampir tidak terlepas dari perbedaaan. Pengakuan dari keluarga salah satu keluarga di lembang Pa'tengko bahwa terkadang mereka juga bertengkar karena pemahana mereka dengan dogma yang berbeda dan keyakinan si anak yang tidak tahu harus mengikut siapa. Akan persoalan itu mereka bisa atasi dengan mengembangkan sikap yang hospitalis. Berkenan dengan kemampuan mengembangkan sikap yang hospitalitas untuk mencega terjadinya kekacauan dalam keluarga, saya mencoba meneliti salah satu keluarga yang tinggal di Pa'tengko. Meski dalam perbedaan (agama) namun mereka terus merasakan hidup rukun yang terwujud dalam aspek kehidupan mereka. Dalam keluarga ini mereka saling bekerja sama dalam kehidupannya. Dalam kegiatan keagamaan pun mereka saling menghormati. Contohnya saja ketika ada kegiatan keagamaan pelayanan dari Gereja dan juga dari Masjid mereka saling bekerja sama dalam menyambut tamu dan juga ketika ibadah sedang berlangsung mereka tidak menghindar akan tetapi mereka hadir sebagaimana keluarga yang utuh.

Fakta hidup damai dalam perbedaan yang hendak diteliti, bahwa bagaimna keluarga ini sehingga bisa hidup rukun? Apa yang menjadi alasan mereka terus hidup dalam perbedaan? Metode penelitian yang akan digunakan untuk mengumpulkan data dan fakta dilapangan adalah jenis penelitian kualitatif, dengan teknik pengumpulan data observasi dan wawancara dan selanjutnya dianalisis dengan teknik analisa data kualitatif deskriptif.

\section{Tujuan dan Manfaat}

a. Tujuan dari penulisan

Tujuan dari penulisan ini adalah untuk mengetahui bahwa sikap yang Hospitalitas dalam keluarga meski berbeda agama, sangat besar pengaruhnya untuk menciptakan keluarga yang rukun

b. Manfaat penulisan

Dengan penulisan ini maka diharapkan dapat menambah wawasan penulis dan pembaca mengenai sikap yang Hospitalitas dalam keluarga.

\section{Pembahasan}

Agama adalah energi yang sangat besar dan mendasar, yang telah membimbing peradaban manusia ke arah pencapaian-pencapain tertingginya yang luar biasa. ${ }^{3}$ Dengan manusia beragama maka peluang manusia untuk hidup bermoral dan lebih meningkat. Karena agama menuntun segalah tatatan kehidupan untuk dapat hidup yang bermanfaat. Agama akan meningkatkan moral dan intelektual bagi para penganutnya.

\section{Konsep Dasar Kerukunan Umat Beragama}

Sejarah bangsa Indonesia tidak terlepas dari nilai-nilai dan ajaran agama-agama di dalam membentuk masyarakat. Agama telah menyatu dan membentuk peri kehidupan sosial, adat-istiadat serta nilai-nilai sosial kemasyarakatan. Kekuatan agama juga telah menyatukan diri bersinergi

\footnotetext{
${ }^{3}$ Bartolomeus Samho, Agama Dan Kesadaran Kontemporer (Yogyakarta: PT Kanisius, 2019), hlm.3.
} 
dengan kekuatan-kekuatan etnis dalam meletakkan pondasi bangsa, meramunya menjadi nilai-nilai dasar bernegara, yaitu Ketuhanan Yang Maha Esa. Berdasarkan nilai-nilai Ketuhanan inilah, bangsa Indonesia telah bersepakat untuk mencapai tujuan bersama untuk mencapai kemanusiaan yang adil dan beradab, keadilan sosial bagi bagi bangsa Indonesia melalui persatuan bangsa, di dalam wadah Negara Kesatuan Republik Indonesia yang demokratis secara politik. Kerukunan umat beragama adalah keadaan hubungan sesama umat beragama yang dilandasi toleransi, saling pengertian, saling menghormati, menghargai kesetaraan dalam pengamalan ajaran agamanya dan kerjasama dalam kehidupan bermasyarakat, berbangsa dan bernegara di dalam Negara Kesatuan Republik Indonesia berdasarkan Pancasila dan Undang-Undang Dasar Negara Republik Indonesia Tahun 1945.

Definisi di atas mengandung beberapa konsep kunci. Pertama, kerukunan yang dimaksud dibangun (oleh) umat beragama yang berbeda-beda agamanya, yang dilandasi toleransi dan kesetaraan. Toleransi merupakan sifat atau sikap saling menghormati perbedaan yang ada (terhadap sesama). Sedangkan setara adalah sama kedudukannya (dalam pengamalan ajaran agamanya). Kedua, adalah kerjasama dalam kehidupan bermasyarakat, berbangsa dan bernegara. Bagian pertama mensiratkan keharusan untuk memiliki pemahaman bahwa hubungan yang dibangun dilandasi kesadaran sebagai umat yang berbeda-beda agama dan keyakinan. Tentu saja perbedaan ini tidak bisa disama-samakan, karena menyangkut keimanan yang transenden bersifat vertikal, termasuk di dalamnya adalah cara masing-masing beribadah kepada Tuhan. Maka yang dikembangkan adalah toleransi. Setiap penganut agama harus mengimani keyakinan agamanya, namun ia harus mengakui bahwa ada orang lain yang memiliki iman berbeda. Sedangkan bagian kedua, bisa dijelaskan bahwa tuntutan untuk bekerjasama adalah orangorangnya, dan hal dikerjasamankan adalah amal perbuatan yang bersifat sosial, bukan dikerjasamakan dalam urusan ke-tauhidan dan peribadatan. Dalam persoalan ini berlaku kaidah "bagimu agamamu bagiku agamaku".

\section{Tantangan Untuk Rukun dan Hidup Berdampingan}

Secara normatif, kewajiban untuk saling menghormati antar sesama, senantiasa diajarkan dan diperintah oleh agama. Bisa dipastikan agama-agama (khususnya) di Indonesia tidak ada satupun yang memerintahkan kepada umatnya untuk saling memusuhi dan berbuat kejahatan kepada lainnya. Yesus juga mengakui adanya dua dosa fatal. Pertama adalah dosa melawan ruh, seperti yg dilakukan para cendekiawan kita yang tidak mempercayai kharisma dan pembawanya. Kedua adalah arogansi tidak bersahabat. ${ }^{4}$

Di dalam iman Kristiani, terdapat ajaran untuk kasih kepada sesama (Mat 22:39). Pengertian sesama tentu saja bukan dalam pengertian sesama umat Kristiani, namun sesama adalah sesama manusia. Di dalam Alkitab, Yesus mengatakan bahwa guru-guru agama (kristiani) harus dinilai sesuai dengan kualitas hasil ajaranny... "bahwa pohon yang baik itu bisa dibedakan dengan pohon yang buruk dilihat dari kualitas buah yang dihasilkannya". Dalam bahasa lain bisa dikatakan bahwa dalam iman kristiani melihat seseorang baik atau buruk juga dilihat dari amal perbuatannya.

\footnotetext{
${ }^{4}$ Max Weber, Sosiologi Agama (Yogyakarta: IRCiSoD, 2012), hlm. 548.
} 
Dalam ke-Tauhidan Islam, konsekuensi ke-imanan seorang muslim ditetapkan dalam dua ranah. Pertama, kewajiban untuk melaksanakan amal-perbuatan vertikal berupa ibadah bersifat transenden (ubuddiyah mahdhah) kepada Allah SWT. Kedua, kewajiban berbuat baik kepada sesama yang bersifat horizontal. Di dalam kaidah Islam 'ala ahlus sunnah wal jama'ah hubungan sesama manusia secara horizontal, diatur dalam hubungan sebagai sesama muslim, hubungan sesama bangsa, serta hubungan sama-sama sebagai umat manusia. ${ }^{5}$

\section{Hospitalitas dalam Keluarga yang Berbeda Agama di Tengah Paham yang Ekstrim}

Hasil penelitian menunjukkan ada beberapa paham dan nilai yang mendasari sehingga mereka termotivasi menolak pengaruh dan doktrin. Dengan demikian mereka hidup dan menunjung tinggi perbedaan dan toleransi.

\section{a. Menghidupi Nilai Kekeluargaan.}

Keluarga berasal dari bahasa Sansekerta,kula artinya saya dan warga yang artinya orang disekitar kita. Keluargamemiliki makna orang yang masih sealiran darah dengan kita. Keluarga adalahsatu unit sosial yang terdiri dari dua atau lebih orang yang dihubungkan olehikatan darah, ikatan perkawinan, atau adopsi dan hidup/tinggal serumah ataumungkin tidak serumah. Keluarga merupakan unit terkecil dari masyarakatyang terdiri atas kepala keluarga dan beberapa orang yang terkumpul dantinggal di suatu tempat di bawah suatu atap dalam keadaan salingketergantungan. Menurut Salvicion dan Celis (1998) di dalam keluarga terdapatdua atau lebih dari dua pribadi yang tergabung karena hubungan darah,hubungan perkawinan atau pengangkatan, hidupnya dalam satu rumah tangga,berinteraksi satu sama lain serta di dalam perannya masing-masingmenciptak an serta mempertahankan suatu kebudayaan. Keluarga sebagaikelompok sosial terdiri dari sejumlah individu, memiliki hubungan antar individu,terdapat ikatan, kewajiban, dan tanggung jawab di antara individu tersebut.

Demi kepercayaan yang dianutnya dan demi kebernaran yang diyakininya, seseorang dapat berbuat apa saja termasuk mengorbankan jiwa raganya (martir). ${ }^{6}$ Dalam rumah tangga ini mereka masing-masing menghidupi apa yang dikatakan kitab sucinya. Contohnya dalam Alquran menegaskan bahwa kewajiban untuk menolong kerabat. Hubungan kekerabatan adalah hubungan saling melengkapi dan saling mencukupi satu dengan yang lain. Alquran mengajarkan dan mendorong pengikutnya untuk silahturahmi, membangun relasi yang baik dengan sesama manusia. Lebih lanjut lagi dikatakan dalam Alquran QS An-Nisa',4:1 “bertaqwalah kepada Allah dengan namanya kamu saling meminta dan peliharala hubungan kekeluargaan, sesungguhnya Allah selalu menjaga dan mengasihimu".

Dari sudut pandang agama Kristen, kitab suci (Alkitab) mengatakan "jika ada seseorang yang tidak memelihara sanak saudaranya, apalagi seisi rumahnya orang itu murtad dan lebih buruk dari orang yang tidak beriman.(1 Tim 5:8)mengatakan " dalam keluargalah orang harus memulai

\footnotetext{
${ }^{5}$ M. Idham Kholiq, Peluang Dan Tantangan Hidup Berdampingan Antara Umat Beragama, (www.fkubsidoarjo.com, diakses pada 17 April 2021, 19.32).

${ }^{6}$ Sindung Haryanto, Sosiologi Agama (Yogyakarta: Ar-Ruzz Media, 2016) hlm. 29.
} 
kehidupan yang saling mengasihi dan menghormati. "Kasihilah sesamamu manusia seperti dirimu sendiri" (Mat 22:39). kasih kepada sesama manusia juga ditekankan oleh Yesus. Jadi dari perspektif umat Kristen umat dituntut untuk menampakkan kasih, dan kasih itu hendaknya dinampakkan dalam hubungan kekerabatan dan keluarga, karena merupakan relasi iman melalui penerimaan pada keluarga dengan kelebihan dan kekurangannya.

\section{b. Penanaman Nilai Toleransi dalam Keluarga.}

Sebagai orang tua, mereka mempunyai peran penting dalam memberi contoh dan mengajar kepada anggota keluarga dalam hal ini anak untuk hidup dalam perdamaian dan menumbuhkan sikap yang toleransi. Orang tua memberi teladan bagaimna sikap yang menghargai dan saling bekerja sama. Orang tua sebagai iman bagi anak-anak menanamkan intelektual yang sehat pada anak. Orang tua mengajarkan pada anak bagaimana sopan santun. Terbukti bahwa ketika ada kegiatan pelayanan ibadah dari Gereja dan Masjid semua anggota keluarga berpartisipasi dalam persiapan penyambutan tamu. Juga ketika ibadah/perkunjungan terjadi semua anggota keluarga hadir serta menampakkan sikap yang hospitalitas. Mereka tidak membeda-bedakan kegiatan keagamaan. Bagi kedua orang tua, mereka tidak memaksa sang anak untuk masuk di agama tertentu, akan tetapi memberikan kebebasan pada anak untuk memilih sesuai kata hatinya. Sikap yang dimiliki oleh anggota keluarga yang menunjung tinggi toleransi membawah keharmonisan dalam keluarga.

\section{c. Mengedepankan Hidup dalam Damai}

Damai merupakan situasi dimana tidak ada perang dan kerusuhan. Damai berarti hidup tentram, tenang, keadaan tidak bermusuhan atau hidup rukun. Hasil wawancara yang didukung oleh observasi menunjukkan bahwa keluarga ini jarang skali terjadi percekcokan dalam rumah tangga mereka. Bahkan di mata masyarakat keluarga ini hidup harmonis dan bermasayarakat tentunya. Sampai sekarang belum perna pertikaian yang hebat terjadi dalam rumah mereka, (masalah itu sudah realistis terjadi, akan tetapi mereka bisa mengatasi, sehingga tercipta lagi kedamaian).

Menurut pengakuan dalam keluarga ini, ada empat hal yang mereka terapkan dalam mengatasi masalah dalam keluarga. Yang pertama dengan menjahuan sikap yang egois antara mereka sehingga masalah atau perselisihan cepat redah atau cepat selesai. Yang ke dua sadar diri. Sadar diri merupakan sikap yang jarang skali diperlihatkan oleh seseorang. Namun dalam keluarga ini mereka mengaku bahwa sadar diri ketika melakukan kesalahan. Dari kesadaran ini segera mengintropeksi diri dan meminta maaf atas kesalahan yang iya lakukan. Dan hal yang ke tiga adalah memaafkan. Sikap yang memaafkan berarti menerima kekuranagan dan kelebihan dalam anggota keluarga. Sikap yang memaafkan mereka jadikan budaya yang menciptakan kedamaian. Dan yang keempat adalah mengetahui hak dan tanggung jawab setiap anggota keluarga. Dengan mengetahui hak dan tanggung jawab setiap anggota keluarga, mereka juga menjalankan perannya masing-masing tanpa ada unsur paksaan

\section{Kesimpulan}


Hal terpenting dalam membangun keluarga yang rukun meski dalam perbedaan beda agama adalah toleransi. Mengembangkan toleransi dalam hubungan sesama umat beragama dengan cara mengakui adanya perbedaan, namun menghormati kebenaran agama orang lain berdasarkan keyakinan masing-masing adalah pertanda harmoni dalam perbedaan. Artinya kita bisa hidup berdampingan satu sama lain, dengan tetap menyadari adanya perbedaan. Tantangan memang ada terutama bersumber dari tafsir atas teks agama itu sendiri. Menumbuhkan sikap yang hospitalitas dalam keluarga merupakan hal yang sangat penting demi terciptanya keluarga yang rukun dalam perbedaan. Sikap yang terbuka dan mengetahui tugas dan tanggung jawab dari anggota keluarga juga mengurangi terjadi perselisihan dalam keluarga.

\section{Pustaka}

Panuntun,D.F.2020.Teologi Kontekstual dan Kearifan Lokal Toraja. Jakarta: BPK Gunung Mulia Sampe, Naomi.2020. Teologi Kontekstual dan Kearifan Lokal Toraja. Jakarta: BPK Gunung Mulia. Samho, Bartolomeus. 2019. Agama dan Kesadaran Kontemporer. Yogyakarta: PT Kanisius. Weber,Max. 2012. Sosiologi Agama. Yogyakarta: IRCiSoD.

Haryanto, Sindung. 2016. Sosiologi Agama. Yogyakarta: Ar- Ruzz media. 